KEYWORDS

Economic concentration

Large enterprises

Capital assets

Investments

Economic indicators

Regression analysis

Economic growth

Mexico

\section{Germán Alarco}

Principal Research Fellow and

Professor at CENTRUM Católica

(Business School) of the Pontificia

Universidad Católica del Perú

๑ galarco@pucp.edu.pe

Patricia del Hierro

Professor at the University

of Piura, Lima Campus

๑ pathierro@hotmail.com
CEPAL REVIEW 101 AUGUST 2010

\section{Growth and concentration among the leading business groups in Mexico}

\author{
Germán Alarco and Patricia del Hierro
}

$\mathrm{T}$

his article discusses various hypotheses relating to the origin and operation of business groups in Mexico, and it proposes a model to explain the sources of their total asset growth. It highlights their growing contribution to Mexican GDP, but notes that their shares of employment and profits are smaller. Over time, sales and assets have clearly tended to become more concentrated in the largest groups. The paper concludes that the main financing sources for asset growth between 2005 and 2007 were firstly debt and secondly capital contributions from shareholders. It also finds that the leading groups invest discretely over time and tend to "overinvest" to block the entry of other competitors. 


\section{I}

\section{Introduction}

The presence of business groups has been a longstanding and important source of debate because they account for a large share of production, investment and employment in some countries; and they have been the protagonists of industrialization processes in many cases. The recent return to more specialized and less diversified business structures has not diminished their preponderance internationally. This view of business groups coexists with others that see them as reflecting market distortions or failures with the potential to impair competitive processes.

The study of enterprises and business groups in Mexico is not recent. Basave and Hernández (2007, pp. 94-119) review its evolution, starting with the pioneering work of Cossío Villegas and Ceceña in the 1970s, which focused on industrialization and monopolies. Subsequently, in the import-substitution strategy and closed-economy phase, the focus was turned towards concentration in the different sectors and branches of the economy, and on the role of foreign direct investment (FDI). In the 1980s, industrial development tended to be explained in terms of the influence of financial capital (before and after the 1982 crisis); and, more recently, the approach has sought to explain trans-nationalization and the export dynamic of large Mexican firms.

In the real world, Latin American business groups, including Mexican ones, have arisen mainly in three periods (Mortimore and Peres, 2001, p. 51). During the country's first industrialization wave at end of the nineteenth century, business groups created large manufacturing factories that were not formally integrated, and set up banks to finance them. In the second industrialization wave starting in the 1930s, a network of firms emerged that were held together through holding companies (Chavarín, 2006, pp. 195-196). In the third wave, new business groups were formed as part of the neoliberal productive restructuring - characterized by privatization, deregulation and globalization - which began in

$\square$ The authors are grateful to Malcolm Stewart Robles for general research assistance, and to the anonymous referees for their comments on the paper. the 1980s (Fernández, 2000, p. 97). Among the 10 leading Mexican groups, three large groups stand out: Slim, Zambrano-Cementos Mexicanos (Cemex) and Salinas Pliego-Elektra.

The universe of large firms located in Mexico includes transnational enterprises, the strengthening and modernization of traditional groups and the emergence of new and very powerful conglomerates formed since the 1980s. Domestic firms grew rapidly in size and developed into a medium-sized transnational structure, as a result of goods and capital exports, while ownership maintained the traditional profiles (Garrido, 1997, pp. 8-9). In response to trade liberalization and the North American Free Trade Agreement, firms targeting the domestic market entered strategic partnerships with foreign firms, raised entry barriers (through preventive investments), and deployed a combination of market power and political relations (Garrido, 2001, pp. 2-3).

This article has several aims. Firstly, it will briefly review explanations of the origin and maintenance of business groups, and propose a model to explain the sources of total asset growth. Secondly, it will present and process statistical data to assess the importance of the leading groups in the Mexican economy in terms of gross domestic product (GDP), employment and profits. Thirdly, it will explore the growth dynamic of Mexican business groups between 2004 and 2007, based on the model developed in the first part and on a cross-section equation.

The article consists of three sections and final thoughts. The first part reviews and evaluates the concepts of diversification, synergy, networks, various hypotheses on the emergence and operation of business groups, and a simple model to explain the sources of asset growth among those groups. The second part discusses the importance of these groups in the Mexican economy and the levels of asset, liability and capital concentration within them. The third section explores the growth sources of these groups during the period under analysis. Lastly, two annexes set out the data used in the regression analysis.

This article does not analyse the transnational firms or medium- and small- scale enterprises with which the most important Mexican business groups coexist. The leading Mexican enterprises are assumed 
to act under the business-group modality. The paper also does not review the history of large Mexican business groups and their relations with the State, nor does it analyse the specific behavior of any of them in times of boom (Garrido, 2002; Castañeda, 2004) or crisis (Garrido, 2001).

\section{II \\ Diversification, contribution and growth possibilities of business groups}

The fundamental issue for defining business groups is diversification. While this concept and how to measure it do get discussed, the most traditional approach is to define the business group in terms of active participation in various different business areas that may or may not be related (Huerta and Navas, 2007, pp. 134-135). The next issue to consider is the relation between diversification and business results. Here, the same authors claim that the link between diversification and results remains inconclusive, despite numerous studies. Nonetheless, they infer, firstly, that diversified firms achieve better results than single-business enterprises, ceteris paribus; and firms that are diversified within related areas perform better than those whose diversification is unrelated (ibid., pp. 138 and 141).

The synergy and network concepts are fundamental for understanding business groupings. In the case of synergy, Huerta and Navas (2007, pp. 137-138) state that related resources between businesses generate synergies (the whole is greater than the sum of the parts) that enhance overall corporate value; whereas formal and informal networks provide a way to reduce transaction costs in the market by choosing less expensive resources. Such networks can also be viewed from the social standpoint, prioritizing personal contacts as a key tool for obtaining the desired results (Levanti, 2001, p. 1,046).

The term "business group" should be understood as a form of business network that arises from a specific combination of organizational architecture and corporate governance, in which a group of firms is controlled by a small number of large shareholders, usually members of an extended family or a closed circle of associates with mutual social ties. Transactions between the firms in a group are usually sustained over the long term and respond to institutional shortcomings, such as the functioning or formation of certain markets (credit, for example), the availability of certain workers or inputs, the presence of market failures; or else they are explained in economic-policy, sociological, culturalist or other terms (Chavarín, 2006, pp. 194 and 195).

The market-failure or imperfections approach claims that business groups overcome difficulties in obtaining capital, specialized labour, raw materials, components and technology in emerging economies (Guillén, 2000, p. 363). Along the same lines, Rendón (1997, p. 5) argues that groups emerge in response to the uncertainty of guaranteeing quality and timely delivery of the inputs they need for production and sales.

The second approach, favoured by sociologisteconomists, argues that firms replicate the surrounding social structure, such that patterns of vertical, horizontal and reciprocal authority affect business organization and relations between firms. These patterns of authority are assumed to be relatively stable through time and resistant to external pressures. Key examples can be found in the Republic of Korea (vertical structure), Taiwan Province of China (horizontal), and Japan (reciprocal). In the third approach, the growth of business groups in newly industrialized countries is associated with policies to promote economic development implemented by the Government or banks, or both, in which the Government prefers to deal with few enterprises as agents of the private sector (Guillén, 2000, pp. 363 and 364).

Another way of visualizing theories that explain the emergence of business groups has been proposed by Tarziján and Paredes (2006, pp. 56-58), who argue that the structure of business groups originally reflected the economic incentives prevailing in the region at the time; and that this organizational structure is now less useful and has varied, as a result of changes in the institutions that gave rise to those incentives. Moreover, the hypothesis propounded by these authors is that business groups form and consolidate to generate a 
structure and network of influences that affords them access to political power and, thereby, enhances their economic capacity and action.

Khanna and Yafeh (2007, pp. 333, 336-341) set forth and analyse six hypotheses to explain the formation of business groups, the persistence of such groups in different settings, and some of their welfare implications. The first hypothesis claims that diversified business groups are more common in economies that have less developed market institutions. Following an extensive bibliographic review, they conclude that capital-market under-development is not a decisive factor in forming a business group. Apparently, other types of institutions and situations are more important, such as vague labour laws, low skill levels among workers and managers, or a desire to reduce the tax burden. There is also no clear linear correlation between greater diversification and higher profits. In general, the results are ambiguous, for example in the Chilean case - with well developed capital markets and more or less clear labour laws - the formation of groups with diversification aims has intensified.

The second hypothesis developed by Khanna and Yafeh (2007, pp. 341-343) argues that the formation of business groups, through vertical integration and the volume of intragroup exchange, tends to be greater when legal and judicial institutions are poorly developed, implying higher contracting costs. The evidence does not support this hypothesis, however, and vertical integration would seem to be more reflective of a firm's desire to increase its monopoly power. The third hypothesis claims that the formation of pyramid-type groups (controlled by a few shareholders) is common in countries where the law provides weak protection for investors. This in turn forces investors to seek a discount when they buy shares in a firm belonging to an business group.

No evidence has been found to support this hypothesis. Pyramid groups tend to form in cases where the State has implemented laws to support or protect industries, for example the Chaebol of the Republic of Korea. Group formation in such cases has more to do with stabilizing earnings rather than maximizing them. Moreover, these groups seek to spread the support and subsidies they receive from the State among their members. Group structures also enable firms to overinvest for the purpose of erecting defences or barriers against other domestic or external competitors.

The fourth hypothesis states that family control of business groups is more common in countries where laws are inadequate and transactions with third parties are costly. Such groups also continue to exist for societal reasons going beyond family ties. The family presence tends to be greater in countries that have poorly developed institutions and markets. For example, in Singapore and Malaysia, nine out of 10 and 35 out of 50 groups had managers drawn from the respective controlling families. Similarly, there are social, cultural, institutional and other factors extending beyond the purely economic rationale, which determine and influence the creation, preservation and operation of business groups (Khanna and Yafeh, 2007, pp. 348-351).

The fifth hypothesis argues that while the creation, expansion and diversification of business groups occurs as a result of government support, their profitability depends on the skills and opportunities they succeed in harnessing. Thus, evidence shows that business groups in many countries were formed thanks to deliberate support from the Government. Nonetheless, while it was possible to confirm that such support is very important to the formation of business groups, in other countries, groups have also arisen with little or no government help. The general pattern, however, is that the vast majority of business groups initially consist of families with very close links to the Government of the day.

Under their own dynamic, business groups accumulate both economic and political influence and power. This causes their relation with the State domain to be fluctuating, ambiguous, and changing, which sometimes elicits a reaction by the State to try to reduce their influence. As a result, their representatives have to lobby intensively to avoid falling out of favour with the authorities. In some circumstances, groups also confront the State, for example in attempts to resist anti-trust and other similar regulations. Khanna and Yafeh (2007, pp. 352-361) find a fruitful relation between the State and business groups, which also has its setbacks since it involves a game between the two parties, and the games are typically complex. Although they cohabit, their coexistence is not easy.

The final hypothesis proposed by Khanna and Yafeh (2007, pp. 361-362) focuses on the fact that business groups engage in a number of uncompetitive practices that tend to increase market power; and this monopoly power is reflected in high rates of profit - especially when they can establish trade barriers and the regulatory framework promoting competition is weak. On this point, it is not entirely clear whether increasing the degree of monopoly 
increases profits. In such variable environments, it impossible to create stable conditions to guarantee a given level of monopoly and abundant profits; and perhaps this explains why business groups are forever trying to influence government decisions.

Following this bibliographic review, we now design a model to explain the sources of expansion of business groups, based on a breakdown between domestic financing (retained profits) and external financing. The starting point is the balance sheet of these groups, where the year-on-year change in total assets $(A)$ in a given year, compared to the previous one, is equal to the sum of year-on-year variations of liabilities $(L)$ and capital $(E)$. Total assets include financial assets (including investments), fixed and other assets, reflecting the fact that a group can expand through different channels. Equation (2) shows these changes in discrete terms, where the asset growth may be financed through debt (liabilities) or equity.

$$
\begin{gathered}
A_{t}-A_{t-1}=\left(L_{t}-L_{t-1}\right)+\left(E_{t}-E_{t-1}\right) \\
\Delta A=\Delta L+\Delta E
\end{gathered}
$$

This article will not discuss the constraints on external financing, but it is clear that this is possible provided certain proportions are maintained in relation to equity growth. Normally, no group will borrow in excess of the standards of the activity in question, which traditionally are related to a given proportion of the capital contributions made by the partners in the business group. Capital growth occurs as a result of profits earned in the fiscal year $(P)$ and capital expansions, either direct or through the stock market (NS). The group's external debt is defined as a proportion of the increase in equity, considering two ratios linked to the total of liabilities with respect to total assets $(\alpha)$ and assets in relation to capital $(\beta)$ of equations (3) and (4), which are substituted in equation (2) to obtain (5).

$$
\frac{L}{A}=\alpha
$$

$$
\frac{A}{E}=\beta
$$

$$
\Delta A=(1+\alpha \beta)(N S+P)
$$

Profits can be explained by various traditional variables, such as the product of return on equity (roe) and capital in equation (6); or the return on sales (ros) multiplied by total sales $(S)$, the latter being the product of the business group's share of the total sales of the activity $(\chi)$, the activity's share in GDP $(\boldsymbol{\delta})$, and GDP itself, as shown in equation (7). No distinction is made here between profits and retained profits after dividend distribution.

$$
\begin{gathered}
\Delta A=(1+\alpha \beta)(N S+\text { roe } E) \\
\Delta A=(1+\alpha \beta)[N S+\operatorname{ros}(\chi \delta Y)]
\end{gathered}
$$

The total-asset growth of any business group is explained directly by the growth of output; ${ }^{1}$ the possibilities of increasing capital with the same partners, new partners (or both); or through the stock market. Asset growth is also affected directly by the ratios liabilities/total assets, total assets/capital, and return on sales of the business group, and by share of the firm and activity in the economy.

\footnotetext{
${ }^{1}$ For simplicity, the analysis excludes external sales, which would depend on the dynamic of the product or service internationally and its external competitiveness.
} 


\section{III \\ Participation by business groups in the Mexican economy}

The available statistical information on national business groups comes from the journal Expansión, which publishes a report on the 100 largest firms in Mexico every year between late April and June. This publication provides information on domestic enterprises and the firms under their control ranked in descending order. For the purposes of this article, information has been selected from the last four years (2004-2007), published between 2005 and 2008, since it is more homogeneous. ${ }^{2}$ These 100 leading enterprises, which engage in various economic activities, do not generally operate in isolation, but form large organizations that function as business groups (Rendón and Morales, 2008b, p. 1,184).

The report presents the following information for each business group: sales, stockmarket capitalization, volume traded on the Mexican stock market, number of workers, net profit, return on equity (roe), the ratio between the share price and earnings per share at the end of December each year, and the asset/debt ratio. To supplement this information, it also shows market share and the index of economic power calculated by Expansión. In the first year only (2004), the report also contains records on total assets and equity.

We used partial the information provided by Expansión for 2004, 2005, 2006 and 2007 to estimate total assets, liabilities and capital for each and every group. Equity $(E)$ was estimated on the basis of knowledge of net profit for the fiscal year $(P)$ and the rate of return on equity (roe) shown in equation (8). Total liabilities $(L)$ were determined from the accounting identity which states that total assets are equal to liabilities plus equity, as shown in equation (9). Dividing each side of this expression by $(L)$ gives the ratio between total assets and liabilities, as shown in equation (10).

$$
\text { roe }=\frac{P}{E}
$$

2 The information contained in Expansión on the 100 Mexican enterprises goes back further, but unfortunately it is not comparable over time.

$$
\begin{aligned}
& A=L+E \\
& \frac{A}{L}=1+\frac{E}{L}
\end{aligned}
$$

The results thus obtained revealed a number of inconsistencies in the information. In some enterprises, the value of total assets, liabilities and equity were sharply different between 2006 and 2007. It was found that the inconsistencies occurred when returns on equity changed significantly without any relation to what was happening with net profits. The case of the first Mexican group (Slim) is illustrative, since return on equity (roe) fell from $26.4 \%$ to $12.6 \%$ between 2006 and 2007 , while profits rose from 77,450 million pesos to 122,370 million pesos, and the ratio total assets/ liabilities remained constant at 1.6.

To correct this problem, various alternatives were evaluated, considering ranges in the variation in sales, in roe, in net profit, and in the total assets/debt ratio. These were evaluated conceptually and then applied to the database. Nonetheless, a new criterion was ultimately adopted whereby the roe for 2007 would be equal to that of the previous year (2006), multiplied by the profits of 2007 and divided by the profits of 2006. This made it possible to avoid sharp variations in capital, and hence in liabilities and in total assets. Moreover, to guarantee data consistency, it was decided to eliminate all information from the enterprise or business group for a given year if data were missing on total assets, liabilities or equity. Maintaining that enterprise would have meant affecting the balance of the sum of balance sheets (or the financial situation statement).

For the 100 largest enterprises in Mexico, table 1 shows their GDP, wage-earning employment, the employed population and operating profits for the years under analysis. To analyse the degree of concentration or dispersion, information is also presented for the first five groups (6 - 10) and for groups 11-20, 21-30, 31-40, 41-50 and 51-100.

The total sales of the 100 enterprises with respect to GDP grew between 2005 and 2007, reaching the equivalent of $22.9 \%$ of GDP in the latter year. 
TABLE 1

Contribution of Mexican business groups to GDP, employment, and operating profits

(Percentages)

\begin{tabular}{|c|c|c|c|c|c|}
\hline \multirow[t]{2}{*}{ Groups } & \multirow[t]{2}{*}{ Year } & \multirow{2}{*}{$\begin{array}{l}\text { Gross domestic } \\
\text { product }\end{array}$} & \multicolumn{2}{|c|}{ Employment } & \multirow[t]{2}{*}{ Operating profit } \\
\hline & & & Wage- earners & Employed population & \\
\hline \multirow[t]{4}{*}{ Groups 1 - 5} & 2004 & 11.87 & 2.05 & 1.17 & 2.12 \\
\hline & 2005 & 9.60 & 1.70 & 1.00 & 2.03 \\
\hline & 2006 & 10.09 & 1.68 & 1.01 & 2.08 \\
\hline & 2007 & 10.65 & 1.78 & 1.08 & $\cdots$ \\
\hline \multirow{4}{*}{ Groups $6-10$} & 2004 & 3.47 & 0.68 & 0.39 & 0.50 \\
\hline & 2005 & 2.77 & 0.95 & 0.56 & 0.47 \\
\hline & 2006 & 2.51 & 0.73 & 0.44 & 0.44 \\
\hline & 2007 & 3.48 & 0.97 & 0.59 & $\ldots$ \\
\hline \multirow[t]{4}{*}{ Groups $1-10$} & 2004 & 15.34 & 2.73 & 1.56 & 2.62 \\
\hline & 2005 & 12.37 & 2.66 & 1.56 & 2.50 \\
\hline & 2006 & 12.59 & 2.42 & 1.45 & 2.51 \\
\hline & 2007 & 14.13 & 2.75 & 1.66 & $\ldots$ \\
\hline \multirow[t]{4}{*}{ Groups $11-20$} & 2004 & 3.32 & 0.97 & 0.55 & 0.44 \\
\hline & 2005 & 3.08 & 0.89 & 0.52 & 0.47 \\
\hline & 2006 & 4.09 & 1.24 & 0.75 & 0.52 \\
\hline & 2007 & 3.36 & 1.16 & 0.70 & $\ldots$ \\
\hline \multirow[t]{4}{*}{ Groups $21-30$} & 2004 & 1.57 & 0.64 & 0.37 & 0.08 \\
\hline & 2005 & 2.10 & 0.66 & 0.39 & 0.20 \\
\hline & 2006 & 2.03 & 0.68 & 0.41 & 0.19 \\
\hline & 2007 & 2.17 & 0.72 & 0.44 & $\ldots$ \\
\hline \multirow[t]{4}{*}{ Groups $31-40$} & 2004 & 1.21 & 0.38 & 0.22 & 0.09 \\
\hline & 2005 & 1.57 & 0.46 & 0.27 & 0.12 \\
\hline & 2006 & 0.99 & 0.35 & 0.21 & 0.11 \\
\hline & 2007 & 1.27 & 0.36 & 0.22 & $\ldots$ \\
\hline \multirow[t]{4}{*}{ Groups $41-50$} & 2004 & 1.18 & 0.29 & 0.17 & 0.07 \\
\hline & 2005 & 0.40 & 0.20 & 0.12 & 0.08 \\
\hline & 2006 & 0.78 & 0.33 & 0.20 & 0.07 \\
\hline & 2007 & 0.51 & 0.21 & 0.13 & $\ldots$ \\
\hline \multirow[t]{4}{*}{ Groups $51-100$} & 2004 & 1.51 & 0.47 & 0.27 & 0.03 \\
\hline & 2005 & 1.49 & 0.51 & 0.30 & 0.12 \\
\hline & 2006 & 1.58 & 0.53 & 0.32 & 0.11 \\
\hline & 2007 & 1.49 & 0.61 & 0.37 & $\cdots$ \\
\hline \multirow[t]{4}{*}{ Total } & 2004 & 24.13 & 5.48 & 3.14 & 3.32 \\
\hline & 2005 & 21.01 & 5.39 & 3.16 & 3.49 \\
\hline & 2006 & 22.06 & 5.54 & 3.33 & 3.51 \\
\hline & 2007 & 22.91 & 5.81 & 3.51 & $\ldots$ \\
\hline
\end{tabular}

Source: Prepared by the authors on the basis of data obtained from the journal Expansion and from the National Institute of Statistics, Geography and Information (INEGI).

Nonetheless, this was a smaller share than in 2004. The first five groups alone account for $10.7 \%$ of GDP; while the first 10 produced $14.1 \%$ of GDP in 2007 , groups $11-20$ contributed $3.4 \%$; groups $21-30$ contributed 2.2\%; groups $31-40$ contributed $1.3 \%$; groups 41-50 contributed 0.5\%; and groups $51-100$ contributed 1.5\% of GDP. Between 2005 and 2007, there is a greater concentration of national output in domestic groups generally, although less among the first 10 groups.

Is worth noting that GDP grew between $3 \%$ and $3.5 \%$ per year in the period under analysis, quite close to the long-term historical average, despite the fact that oil prices were rising. Inflation rates fluctuated between $5.2 \%$ and $3.3 \%$ per year, while the exchange rate against the dollar remained broadly stable. The purchasing power of wage earners, the external sector, the financial sector and public finance all maintained their trends of previous years.

The 100 largest enterprises provided just over 1.5 million permanent jobs in 2007, representing an insignificant $5.8 \%$ of total wage-earners (persons receiving wages and salaries) and just $3.5 \%$ of the employed population nationwide. 
Employment is less concentrated than total sales in relation to GDP, since the 10 leading groups provided just $2.8 \%$ of national wage-earning employment in 2007 , and $1.7 \%$ of the total employed population. The first five groups accounted for $1.8 \%$ of wageearning employment, and $1.1 \%$ of the total employed population. Groups 11 to 20 accounted for $1.2 \%$ and $0.7 \%$, respectively, while groups 21 to 30 employed $0.7 \%$ and $0.4 \%$ of the total, in that year.

The share of operating profit is measured by the ratio between the sum of net total profits earned by the selected firms and the total operating profits reported in the national accounts. There is currently no information available on profits for 2007. Nonetheless, between 2004 and 2006, the share of these firms in operating profits nationwide rose from $3.3 \%$ to $3.5 \%$. In the latter case, while the top 10 groups contributed $2.5 \%$ of national profits, in 2004 their share was $2.6 \%$.

With regard to other information sources, Rendón and Morales (2008b, pp. 1,178 and 1,180$1,181)$ argue that concentration in favour of the larger firms and business groups clearly increased. Between 1993 and 2003, large firms employed 21.1\% and $28.4 \%$ respectively of all persons employed in the economy. The 5,000 largest Mexican firms reported by Expansión had net sales equivalent to $18.2 \%$ of GDP in $1990,50 \%$ in 2000 , and as much as $73.5 \%$ in 2004. In the latter year, $5.4 \%$ of these firms were State-owned, $57.8 \%$ were domestic private-sector firms, and $36.8 \%$ were foreign.

Table 2 shows a number of financial ratios applied to the 100 business groups, and also to a selection of those groups by decile. The chosen ratios include the asset turnover rate, defined as total sales divided by the value of total assets. The second ratio measures average output per employed worker, calculated the quotient between total sales and the number of workers, in millions of pesos at current prices. The third ratio, subject to stock-market fluctuations, is the quotient between the groups' market value (stock market capitalization) and total assets. Leveraging ratios are then presented - total liabilities in relation to total assets, and total liabilities in relation to equity. Lastly, the table shows the ratio of net profits to equity as a percentage.

Taking the 100 enterprises as a whole, asset turnover increased between 2004 and 2007, which implies better exploitation of total assets. Groups 11-50 make better use of total assets than the first 10 groups, where turnover is lower. Asset turnover is highest among groups 31-50. The lower turnover of total assets displayed by the top 10 business groups reflects the existence of greater idle installed capacity, stemming from "overinvestment" aimed at erecting entry barriers against competitors, by raising equipment standards. These firms overinvest to raise barriers and would have the capacity to respond more quickly to unforeseen changes in demand. This defensive strategy has also been reported by Mortimore and Peres (2001, p. 54).

The average output per worker for all enterprises analysed has also increased, but only from 2005 to 2007, having fallen between 2004 and 2005 . By decile, the highest value corresponds to the 10 leading enterprises, followed by groups 31-40. The ratio of market capitalization to total assets has also increased between 2004 and 2007, reflecting the better performance of the price index and prices quoted on the Mexican stock exchange. This ratio is also higher in the case of the 10 leading business groups, and among those in positions 31-50.

Leveraging indicators for the period 2004-2007 do not display a clear trend and are less variable in the case of total liabilities/total assets. The other ratio of total liabilities with respect to capital fluctuates more. Both ratios rose between 2006 and 2007. Total liabilities grew to $60 \%$ of total assets, and $148 \%$ of equity set of enterprises as a whole. The 10 leading groups have slightly higher ratios, equivalent to $62 \%$ and $161 \%$, respectively, in 2007 .

The last ratio is the quotient between net profit and equity, which rose from $14 \%$ to $24 \%$ between 2004 and 2007. The top 10 groups have the highest rates of return in all years, whereas the other deciles display lower rates. The larger the size, the higher the absolute and relative returns.

Figure 1 shows concentration levels among total assets, total liabilities and equity, for the 100 largest enterprise groups in Mexico. The 10 largest domestic groups have been increasing their share of total assets: $60.8 \%$ in $2005,62.9 \%$ in 2006 and $66.8 \%$ in 2007 . The top 10 groups had $59.1 \%$ of total liabilities in 2005 , $63.7 \%$ in 2006 , and $69 \%$ in 2007 . Equity shows no clear trend, however, with the share in those years fluctuating between $63.1 \%$ in $2005,61.8 \%$ in 2006 , and $63.5 \%$ in 2007.

These high concentrations are ratified through the Herfindahl-Hirschmann index (HHI), for the various deciles of the 100 leading business groups in Mexico. In this case, the index is defined as the sum of the squares of the shares of total assets of each 
TABLE 2

Financial ratios of Mexican business groups, 2004-2007

\begin{tabular}{|c|c|c|c|c|c|c|c|}
\hline Groups & Year & $\begin{array}{l}\text { Sales/total } \\
\text { assets }\end{array}$ & Sales/workers ${ }^{\mathrm{a}}$ & $\begin{array}{l}\text { Stockmarket } \\
\text { capitalization/ } \\
\text { total assets }\end{array}$ & $\begin{array}{l}\text { Liabilities/total } \\
\text { assets }\end{array}$ & $\begin{array}{l}\text { Liabilities/ } \\
\text { equity }\end{array}$ & $\begin{array}{l}\text { Net profit/ } \\
\text { equity }(\%)\end{array}$ \\
\hline \multirow[t]{4}{*}{ Groups 1 to 10} & 2004 & 0.58 & 2.08 & 0.71 & 0.61 & 1.54 & 15.41 \\
\hline & 2005 & 0.66 & 1.80 & 1.07 & 0.56 & 1.28 & 18.41 \\
\hline & 2006 & 0.81 & 2.12 & 1.58 & 0.55 & 1.22 & 22.04 \\
\hline & 2007 & 0.82 & 2.21 & 1.69 & 0.62 & 1.61 & 28.86 \\
\hline \multirow[t]{4}{*}{ Groups 11 to 20} & 2004 & 0.97 & 1.27 & 0.83 & 0.49 & 0.98 & 15.49 \\
\hline & 2005 & 0.68 & 1.33 & 0.41 & 0.65 & 1.86 & 17.75 \\
\hline & 2006 & 1.07 & 1.34 & 0.75 & 0.54 & 1.15 & 17.96 \\
\hline & 2007 & 1.12 & 1.25 & 1.13 & 0.57 & 1.30 & 16.70 \\
\hline \multirow[t]{4}{*}{ Groups 21 to 30} & 2004 & 0.81 & 0.90 & 0.62 & 0.58 & 1.38 & 5.87 \\
\hline & 2005 & 0.95 & 1.23 & 1.01 & 0.46 & 0.86 & 9.89 \\
\hline & 2006 & 1.19 & 1.22 & 1.13 & 0.57 & 1.33 & 15.85 \\
\hline & 2007 & 1.41 & 1.29 & 1.04 & 0.57 & 1.32 & 18.74 \\
\hline \multirow[t]{4}{*}{ Groups 31 to 40} & 2004 & 0.82 & 1.17 & 0.62 & 0.50 & 1.00 & 7.07 \\
\hline & 2005 & 0.91 & 1.31 & 0.43 & 0.61 & 1.54 & 10.32 \\
\hline & 2006 & 0.77 & 1.15 & 0.76 & 0.55 & 1.20 & 11.83 \\
\hline & 2007 & 1.27 & 1.50 & 1.17 & 0.55 & 1.24 & 8.88 \\
\hline \multirow[t]{4}{*}{ Groups 41 to 50} & 2004 & 1.45 & 1.49 & 0.59 & 0.55 & 1.22 & 11.11 \\
\hline & 2005 & 0.43 & 0.77 & 0.33 & 0.68 & 2.16 & 16.40 \\
\hline & 2006 & 0.98 & 0.95 & 0.88 & 0.55 & 1.22 & 11.55 \\
\hline & 2007 & 0.64 & 1.02 & 1.31 & 0.43 & 0.75 & 17.29 \\
\hline \multirow[t]{4}{*}{ Groups 51 to 100} & 2004 & 0.70 & 1.18 & 0.40 & 0.62 & 1.64 & 2.27 \\
\hline & 2005 & 0.57 & 1.13 & 0.28 & 0.60 & 1.53 & 6.93 \\
\hline & 2006 & 0.98 & 1.22 & 0.44 & 0.45 & 0.83 & 7.64 \\
\hline & 2007 & 0.65 & 1.06 & 0.46 & 0.58 & 1.40 & 8.77 \\
\hline \multirow[t]{4}{*}{ Total } & 2004 & 0.67 & 1.62 & 0.69 & 0.59 & 1.44 & 13.65 \\
\hline & 2005 & 0.68 & 1.51 & 0.84 & 0.58 & 1.36 & 16.16 \\
\hline & 2006 & 0.89 & 1.62 & 1.28 & 0.54 & 1.19 & 19.02 \\
\hline & 2007 & 0.88 & 1.70 & 1.45 & 0.60 & 1.48 & 23.52 \\
\hline
\end{tabular}

Source: Prepared by the authors on the basis of data obtained from the journal Expansion and from the National Institute of Statistics, Geography and Information (INEGI).

a Millions of pesos per worker at current prices.

decile in the total of the 100 groups. ${ }^{3}$ The maximum HHI value is therefore 10,000 when a decile accounts for $100 \%$ of total assets (maximum concentration). A

$3 \mathrm{IHH}=\sum_{i=1}^{n} S_{i}^{2}$, where $S_{i}$ is each group's share in the total. decile can be classified as deconcentrated $(\mathrm{HHI}<1,000)$, moderately concentrated $(1,000<\mathrm{HHI}<1,800)$ or highly concentrated ( $\mathrm{HHI}>1,800)$. The available information shows that asset concentration is clearly very high and increasing through time, since the HHI for 2005 was 4,506.4, compared to $4,672.5$ in 2006, and 5,208.7 in 2007 . 
Distribution of assets, liabilities and equity among Mexican business groups, 2005-2007 (Percentages)

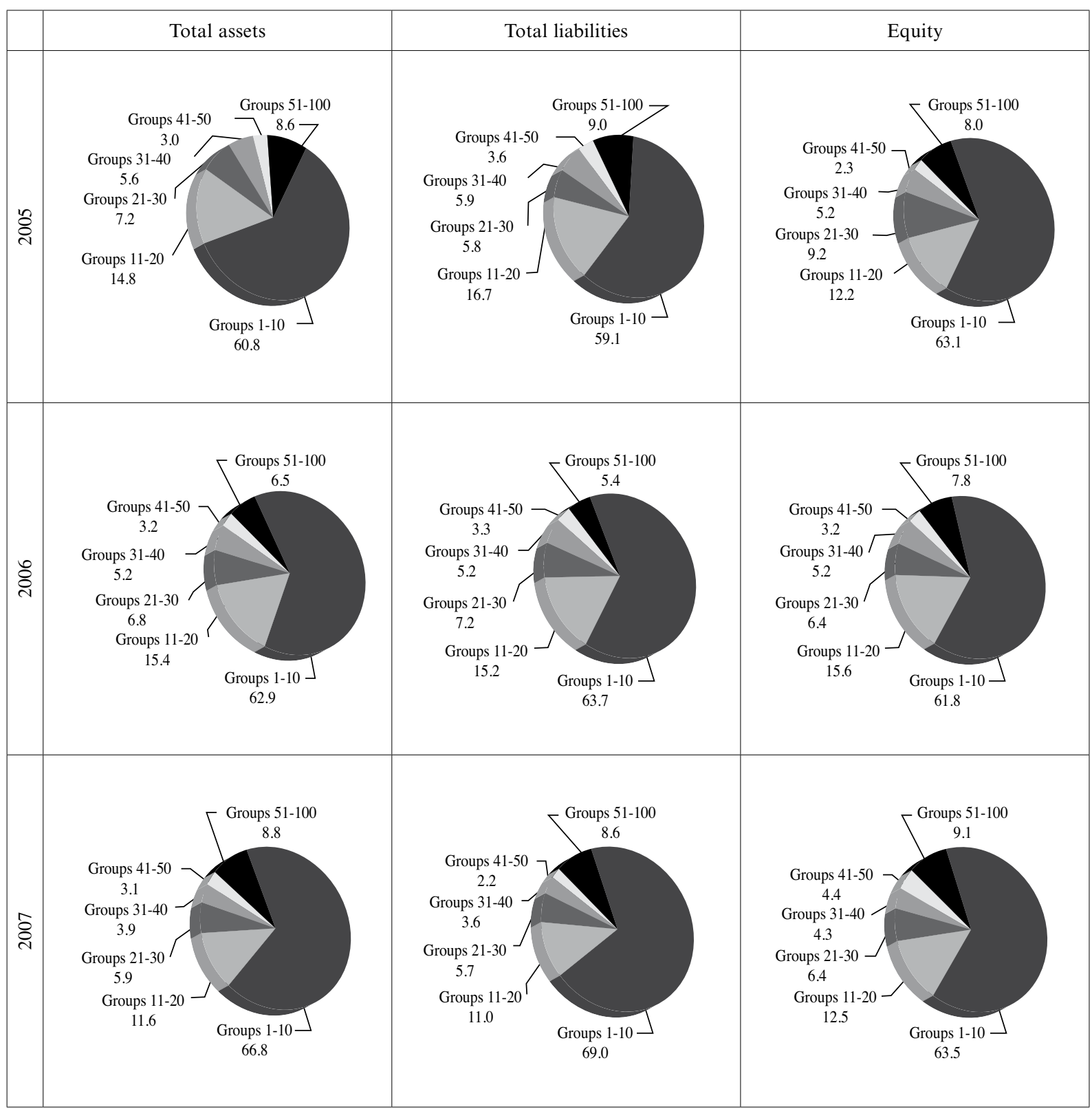

Source: Prepared by the authors on the basis of data obtained from the journal Expansion and from the National Institute of Statistics, Geography and Information (INEGI). 


\section{IV \\ Growth and dynamic of the business groups, 2004-2007}

Table 3 provides data on the key accounting categories for all Mexican firms in 2004 through 2007, in millions of pesos at current prices, including total assets, total liabilities, equity, total sales and net profits. The table includes information not only for the total, but also the first five deciles (positions 1-10, 11-20, 21-30, $31-40,41-50$ ), along with the subtotal of values for firms located in positions 51 to 100 .

An initial aspect to stress is that local sales decreased between 2004 and 2005, along with the total assets, liabilities and the equity of all enterprises. Only net profits grew in that period. There are several possible explanations for this. Firstly, it may reflect the presence of adjustments in accounting criteria ordered by the government authorities, relating to the consolidation of firms in a single business group. Secondly, it may stem from the combination of the accounting criteria mentioned above, with the sale of assets or equity by national groups to foreign owners, although the FDI data for those years do not report a significant increase in assets held by foreigners.

Lastly, it is important to note that the changes that occurred between 2004 and 2005 in some of the top 10 Mexican groups (Slim, Larrea, Fernández,

TABLE 3

Values of the main accounting categories of Mexican business groups, 2004-2007 (Millions of pesos at current prices)

\begin{tabular}{|c|c|c|c|c|c|c|}
\hline Group & Year & Total assets & Total liabilities & Total equity & Sales & Net profits \\
\hline \multirow[t]{4}{*}{ Groups 1 - 10} & 2004 & 2265072.0 & 1374430.0 & 890642.0 & 1314944.0 & 137250.0 \\
\hline & 2005 & 1722874.9 & 966419.7 & 756455.3 & 1141545.5 & 139267.8 \\
\hline & 2006 & 1615730.7 & 888420.5 & 727310.3 & 1302136.5 & 160293.4 \\
\hline & 2007 & 1934035.2 & 1192394.4 & 741640.7 & 1579250.8 & 214041.2 \\
\hline \multirow[t]{4}{*}{ Groups $11-20$} & 2004 & 291554.0 & 143978.0 & 147576.0 & 284168.0 & 22857.0 \\
\hline & 2005 & 419231.0 & 272472.1 & 146758.8 & 283991.4 & 26053.7 \\
\hline & 2006 & 395449.6 & 211700.8 & 183748.8 & 423366.5 & 32995.3 \\
\hline & 2007 & 335344.7 & 189553.9 & 145790.9 & 375056.5 & 24341.3 \\
\hline \multirow[t]{4}{*}{ Groups $21-30$} & 2004 & 167222.0 & 96864.0 & 70358.0 & 134669.0 & 4128.0 \\
\hline & 2005 & 205516.2 & 94855.3 & 110660.8 & 194277.1 & 10948.0 \\
\hline & 2006 & 175905.6 & 100453.0 & 75452.6 & 209954.2 & 11956.9 \\
\hline & 2007 & 172219.9 & 97955.0 & 74264.9 & 242440.5 & 13920.8 \\
\hline \multirow[t]{4}{*}{ Groups $31-40$} & 2004 & 126921.0 & 63579.0 & 63342.0 & 103838.0 & 4481.0 \\
\hline & 2005 & 159153.1 & 96442.0 & 62711.0 & 144607.1 & 6471.5 \\
\hline & 2006 & 133482.0 & 72909.0 & 60573.1 & 102255.7 & 7164.3 \\
\hline & 2007 & 111558.2 & 61808.5 & 49749.7 & 141402.5 & 4417.6 \\
\hline \multirow[t]{4}{*}{ Groups $41-50$} & 2004 & 70022.0 & 38544.0 & 31478.0 & 101312.0 & 3496.0 \\
\hline & 2005 & 85849.4 & 58681.8 & 27167.6 & 36942.6 & 4456.6 \\
\hline & 2006 & 82866.0 & 45510.7 & 37355.3 & 80883.5 & 4314.3 \\
\hline & 2007 & 88971.3 & 38078.4 & 50893.0 & 56676.4 & 8801.8 \\
\hline \multirow[t]{4}{*}{ Groups - to 100} & 2004 & 184840.0 & 114764.0 & 70076.0 & 129632.0 & 1591.0 \\
\hline & 2005 & 242684.5 & 146697.8 & 95986.7 & 137580.6 & 6647.1 \\
\hline & 2006 & 167056.0 & 75553.1 & 91502.8 & 163248.5 & 6995.0 \\
\hline & 2007 & 253811.9 & 147997.0 & 105814.9 & 166019.6 & 9283.2 \\
\hline \multirow[t]{4}{*}{ Total } & 2004 & 3105631.0 & 1832159.0 & 1273472.0 & 2068563.0 & 173803.0 \\
\hline & 2005 & 2835309.1 & 1635568.8 & 1199740.3 & 1938944.3 & 193844.7 \\
\hline & 2006 & 2570489.9 & 1394547.1 & 1175942.8 & 2281844.9 & 223719.2 \\
\hline & 2007 & 2895941.2 & 1727787.2 & 1168154.0 & 2560846.3 & 274805.9 \\
\hline
\end{tabular}

Source: Prepared by the authors on the basis of data obtained from the journal Expansion and from the National Institute of Statistics, Geography and Information (INEGI). 
Garza Medina and Salinas Pliego) explain most of the amounts observed for the 100 leading business groups. The higher level of total assets, liabilities and equity in 2004 compared to the 2005 figures, can also be seen in the deciles containing the smaller business groups, apart from those located in positions 41-50.

The total sales of the 100 leading domestic enterprises increased between 2005 and 2007, while total assets retreated 2005-2006, before recovering between 2006 and 2007. Total liabilities moved in a similar way, contracting again in 2005 and 2006, before rising from 2006 to 2007 . In the case of equity, there has been a slight long-term declining trend despite profits expanding from year to year.

Table 4 shows the annual financial flows of total assets, which are explained by the variation in total liabilities and equity for all of the 100 large Mexican enterprises (presented by decile). Only information for the period 2005-2006 and 2006-2007 is shown, because the period 2004-2005 involves the methodological elements referred to above. As information from just two years in particular is used, it is not considered necessary to transform from millions of current pesos to constant prices basis.

An initial comment on the available information is that the higher sales levels are not supported by changes in total assets: financial, fixed or intangible. These levels, reflecting higher domestic or external demand, stem from higher turnover in relation to total assets and the investment decisions taken discontinuously through time. Given the scant information available, it is impossible to establish other hypotheses on this. From 2005 to 2006, total assets declined, matched by a larger reduction in total liabilities with respect to equity. This phenomenon is general and could be explained by accounting or other reasons.

Between 2006 and 2007, there was significant growth in total assets among the 100 enterprises analysed. Nonetheless, the behaviour is different, because most of the increase is explained by what happened in the top 10 groups, and among the smallest, located in positions 41-100. There is a sharp drop in the value of assets and liabilities among groups 11-40. The other relevant observation, when working with the set of firms as a whole, is that the main adjustment variable are liabilities, with equity fluctuating by less.

As a whole, the 100 largest firms are financed overwhelmingly by third-party capital (liabilities), supported by small equity capital injections. The situation is clear in the case of the 10 leading business groups, whose total asset expansion is financed with liabilities, and to a lesser extent through an equity expansion. In contrast, the latter is more important as a financing mechanism among groups in positions 41-100, especially those ranked 41-50, whose total

TABLE 4

Financial flows of Mexican groups, 2005-2007a

(Millions of pesos at current prices)

\begin{tabular}{lcccc}
\hline Groups & Year & Variation in total assets & Variation in total liabilities & Variation in equity \\
\hline Groups 1-10 & $2005-2006$ & -107144.2 & -77999.2 & -29145.0 \\
& $2006-2007$ & 318304.5 & 303974.0 & 14330.5 \\
Groups 11-20 & $2005-2006$ & -23781.4 & -60771.3 & 36989.9 \\
& $2006-2007$ & -60104.9 & -22147.0 & -37957.9 \\
Groups 21-30 & $2005-2006$ & -29610.6 & 5597.7 & -35208.3 \\
& $2006-2007$ & -3685.7 & -2498.0 & -1187.7 \\
Groups 31-40 & $2005-2006$ & -25671.0 & -23533.1 & -2138.0 \\
Groups 41-50 & $2006-2007$ & -21923.9 & -11100.5 & -10823.4 \\
Groups 51-100 & $2005-2006$ & -2983.4 & -13171.1 & 10187.7 \\
Total = US\$100 & $2006-2007$ & 6105.3 & -7432.4 & 13537.6 \\
& $2005-2006$ & -75628.6 & -71144.7 & -4483.9 \\
& $2006-2007$ & 86755.9 & 72443.9 & 14312.0 \\
\hline
\end{tabular}

Source: Prepared by the authors on the basis of data obtained from the journal Expansión and from the National Institute of Statistics, Geography and Information (INEGI).

a Firms listed as ranked by Expansión 2008 for 2007. 
asset expansion is explained by an increase in equity and a reduction in total liabilities.

Corporate financing through liabilities includes funding through the domestic banking and international banking systems, the issuance of debt securities floated on local and international markets, among the main financial instruments. For reference purposes only, it is interesting to note that between 2006 and 2007, the expansion of liabilities among the 100 leading Mexican business groups accounted for $76.2 \%$ of the increase in lending by the financial system to the private sector, according to data reported in International Financial Statistics published by the International Monetary Fund (IMF, 2009).

Table 5 shows the results of cross-section regressions that aim to explain the growth in sales and total assets between 2005 and 2007, of the groups and businesses reported by Expansión. It is claimed that sales growth depends directly on the fixed-asset turnover ratio and growth of total assets, while the latter would be explained more by growth and liabilities than by contributions made by shareholders (equity). Annexes 1 and 2 provide the basic information used for these regressions, converted into percentage variations to improve the goodness of fit of the regressions.
The results show that the first regression does not reject the hypothesis that the percentage change in sales growth depends positively on the percentage change in the ratio between total sales and total assets, and the percentage change in total assets. The second equation is also unable to reject the hypothesis that the percentage change in total assets depends firstly on the percentage change in liabilities and secondly on equity. There is no direct link with the percentage change in net profits for the fiscal year.

The two equations display a goodness of fit of over and $60 \%$ and $90 \%$, respectively, which are high values for cross-section regressions using percentage variations. The parameters reflect the logic of the hypothesis, since they have the correct signs and are significantly different from zero according to the t-test. Overall, they are also different from zero according to the F-test. Both cases considered data for firms with complete information for the period 2005-2007: 69 in all. Neither regression detected problems of autocorrelation, heteroscedasticity or multicollinearity.

No detailed analysis will be made of the sources of total-asset growth among the leading business groups or enterprises in Mexico, because

TABLE 5

Main results of sales growth regressions

\begin{tabular}{|c|c|c|}
\hline \multirow[b]{2}{*}{ Independent variables } & \multicolumn{2}{|c|}{ Dependent variables } \\
\hline & $\begin{array}{l}\text { Percentage change in sales, } \\
\text { 2005-2007 }\end{array}$ & $\begin{array}{l}\text { Percentage change in assets, } \\
\qquad 2005-2007\end{array}$ \\
\hline Constant & $\begin{array}{c}24.3097 \\
(-3.0426)\end{array}$ & $\begin{array}{c}-3.0039 \\
(-1.8231)\end{array}$ \\
\hline Percentage change in the ratio of sales/assets, 2005-2007 & $\begin{array}{c}0.2794 \\
(10.1443)\end{array}$ & \\
\hline Percentage change in total assets, 2005-2007 & $\begin{array}{c}0.8348 \\
(4.4317)\end{array}$ & \\
\hline Percentage change in total liabilities, 2005-2007 & & $\begin{array}{c}0.5563 \\
(19.3295)\end{array}$ \\
\hline Percentage change in equity, 2005-2007 & & $\begin{array}{c}0.4618 \\
(7.4837)\end{array}$ \\
\hline Percentage change in profits, $2005-2007$ & & $\begin{array}{c}-0.0002 \\
(-0.1210)\end{array}$ \\
\hline $\mathrm{R}^{2}$ & 0.6093 & 0.9092 \\
\hline Adjusted $\mathrm{R}^{2}$ & 0.5974 & 0.9050 \\
\hline $\mathrm{F}$-test & 51.4541 & 216.9358 \\
\hline Durbin-Watson test & 1.8482 & 1.9499 \\
\hline
\end{tabular}

Source: Prepared by the authors on the basis of data obtained from the journal Expansion and from the National Institute of Statistics, Geography and Information (INEGI).

Note: t-test values shown under the respective parameters. 
the secondary information is still fragmented. Nonetheless, it may be interesting to note that from 2006 to 2007, four of the 10 leading domestic groups increased their levels of debt in relative to assets (Zambrano-Cemex, Garza Medina-Alfa, Fernández González-Modelo and González Barrera-Maseca), while three maintained them (Slim, Bailléres-Bal and Salinas Pliego-Elektra) and three reduced them (Larrea-Grupo México, Fernández Carbajal-Femsa and Servitje-Bimbo).

Lastly, unlike other countries, Mexican business groups do not generally have financial institutions either under their control or forming part of the group

\section{V}

\section{Final thoughts}

The formation of business groups in Mexico replicates the dynamic that has unfolded in most Latin American countries. Groups arose mainly during the early industrialization period in the late nineteenth and early twentieth centuries, then during the import substitution process between the 1950s and 1970s, and again following the neoliberal productive restructuring of the 1980s. New groups emerge over time, while some maintain their presence, and others fade away.

Various hypotheses have been put forward to explain the origin and functioning of business groups. An extensive review of the literature shows that many issues are still under discussion and conclusive evidence is scarce. The main arguments claim that groups emerge as a result of failings or shortcomings in various markets, but other explanations also seem to be valid, which posit linkages between these groups and the State. Business groups maintain a complex relation of mutual support with the State (depending on the government); but distancing occurs in some circumstances.

The financial statements of any business group or firm can be used to identify the sources of expansion of total assets (financial, fixed and intangible) as a counterpart to changes in liabilities and equity. The sources of liability growth are domestic and international bank financing, the issuance of national and international debt, and other liabilities. Capital growth occurs through retained profits and new share issues. The proportions between liabilities and capital are determined in accordance with itself. In 2007, only 12 of the 100 leading Mexican enterprises had associated financial institutions or enterprises for which financial services were the core of their activities. In the top 10 national groups, only Slim-Grupo Financiero (GF) Inbursa and González Barrera-GF Banorte have direct financial links; in groups 11 to 20, there are just two: Salinas PliegoBanco Elektra and Del Valle Ruiz-GF Ve por Más and in positions $31-40$, there are just GF Ixe and GF Invex. Positions 51 to 100 include genuine financial groups, but of small national scope: Banco del Bajío, GF Banregio, GF Interacciones, GF Afirme, GF Mifel and GF Monex. domestic and international sector parameters, and the specific evaluation of the financial or business group in question.

Based on available information, it is clear that Mexican business groups are making a growing contribution to GDP, reflecting a process of concentration and centralization of sales, total assets, liabilities and equity in the hands of just a few groups. The contribution of these groups to employment and operating profits is less, however; but this reflects higher levels of productivity than in other firms in the economy. No evaluation has been made of transnational firms and other smaller domestic enterprises.

There is a concentration phenomenon in favour of the 10 leading Mexican business groups, to the detriment of other groups and businesses registered by Expansión. The 10 leading groups account for over $60 \%$ of total assets, liabilities and equity. Between 2005 and 2007, the share of total assets and liabilities has been growing, reflecting increasing concentration; and this seems to be positively correlated with earnings, since return on equity (roe) has also been rising during the period under analysis.

Sales growth among business groups is explained by increases in the fixed asset turnover ratio (total sales/total assets) and the growth of total assets, as can be inferred from a direct analysis of financial information and cross-section regressions. Moreover, the different business groups do not invest continuously through time, but in discrete jumps (sporadically), to exploit specific advantages that may be related 
to the real exchange rate, interest rates, tariffs, and other variables.

Although most Mexican business groups do not have very close relations with firms in the financial sector, as previously was a characteristic feature, in the period under analysis from 2005 to 2007, the main source for financing total asset growth was third-party capital (debt) and a proportionately smaller equity expansion. The leading business groups, particularly the top 10, exploit their position to gain more third-party capital through a higher leveraging than the average among Mexican business groups and enterprises.

Of the 15 largest business groups, three stand out: Slim, González Barrera and Salinas Pliego, which have performed very dynamically since the 1980s and have their own financial institutions. In contrast, the smaller business groups located in positions 41-100 need to draw on equity more than third-party capital to finance their asset growth. Those located in positions 41-50 self-financed the expansion of their total assets in the period under analysis.
The lower asset turnover rate among the 10 leading business groups reflects a feature commented on by other authors, namely that as part of their defensive strategies these firms tend to overinvest, generating entry barriers for competitors. Lower turnover would mean less productive use of their assets; but these firms are willing to accept the opportunity cost of underuse to guarantee growth spaces for their groups. Similarly, it should not be forgotten that these larger groups probably face lower financial costs than other smaller groups and enterprises.

Lastly, an important finding in relation to Mexican business groups is that business networks may be large and more or less complex, and have both offensive and defensive strategies; but the capital structure remains highly traditional, with clear presence and control by a family group in particular. It is also clear that none of the large Mexican groups occupies a significant place in high technology sectors (SalasPorras, 2006a, p. 6).

(Original: Spanish) 
ANNEX 1

Basic statistics for the econometric regressions, 2005-2007 (Millions of pesos at current prices)

\begin{tabular}{|c|c|c|c|c|c|c|}
\hline \multirow{2}{*}{ Business groups/enterprises } & \multicolumn{2}{|c|}{ Sales } & \multicolumn{2}{|c|}{ Total assets } & \multicolumn{2}{|c|}{ Total liabilities } \\
\hline & 2005 & 2007 & 2005 & 2007 & 2005 & 2007 \\
\hline Grupo Carso, América Móvil, Imbursa (Carlos Slim Helú \& Sons) & 495434.1 & 618238.6 & 669234.49 & 782354.99 & 371796.94 & 488971.87 \\
\hline Cemex (Lorenzo Zambrano Treviño) & 162708.6 & 236669.0 & 293138.56 & 370126.53 & 183211.60 & 231329.08 \\
\hline Grupo México (Germán Larrea Mota Velasco) & 58101.8 & 80950.2 & 99512.20 & 81865.12 & 41463.41 & 29237.54 \\
\hline Fomento Económico Mexicano (José Antonio Fernández Carbajal) & 105581.7 & 147556.1 & 127642.28 & 99505.10 & 60782.04 & 45229.59 \\
\hline Grupo Alfa (Dionisio Garza Medina) & 69334.8 & 106832.7 & 61966.70 & 74323.26 & 29507.95 & 41290.70 \\
\hline Grupo Modelo (Carlos Fernández González) & 49550.5 & 72894.6 & 80311.38 & 71325.47 & 12168.39 & 12736.69 \\
\hline Gruma y Banorte (Roberto González Barrera) & 63856.4 & 97308.6 & 240468.45 & 224355.33 & 200390.37 & 186962.78 \\
\hline Grupo Bimbo (Daniel Servitje Montull) & 56102.2 & 72293.6 & 36270.51 & 36797.82 & 16486.60 & 13628.82 \\
\hline Grupo Bal (Alberto Bailléres González) & 57278.4 & 85127.4 & 76248.60 & 104607.88 & 54463.29 & 74719.92 \\
\hline Grupo Salinas Elektra (Ricardo Salinas Pliego) & 47075.9 & 61380.0 & 70101.08 & 88773.67 & 58417.57 & 68287.44 \\
\hline Organización Soriana (Ricargo Martín Bringas) & 48394.4 & 65190.7 & 35798.32 & 54005.17 & 14915.97 & 30002.87 \\
\hline Grupo Televisa (Emilio Azcárraga Jean) & 32481.0 & 41561.5 & 78532.05 & 85121.11 & 35696.39 & 50071.24 \\
\hline Mexichem (Antonio del Valle Ruiz) & 8677.4 & 24236.9 & 91030.97 & 16104.43 & 56894.35 & 11503.16 \\
\hline Grupo Coppel (Enrique Coppel Luken) & 19607.5 & 34752.7 & 18733.54 & 33933.85 & 10407.52 & 22622.57 \\
\hline Empresas ICA (Bernardo Quintana Isaac) & 18404.9 & 22447.8 & 31241.39 & 18372.94 & 18377.29 & 8749.02 \\
\hline Comercial Mexicana (Guillermo González Nova and Carlos González Zabalegui) & 40308.9 & 50409.2 & 30453.33 & 34886.57 & 13842.42 & 15857.53 \\
\hline Liverpool (Max David Michel and Max Michel Souberville) & 32055.2 & 42976.3 & 36910.44 & 42109.51 & 17576.40 & 19140.69 \\
\hline Axtel y Avantel (Tomás Milmo Santos) & 4966.8 & 12190.6 & 10872.34 & 16789.51 & 3749.08 & 9327.51 \\
\hline Grupo Xignux (Eugenio Garza Herrera) & 21983.1 & 39142.7 & 15352.04 & 12737.86 & 9030.61 & 7076.59 \\
\hline Homex (Eustaquio Tomás de Nicolás Gutiérrez) & 8571.4 & 16166.1 & 14143.73 & 17598.52 & 8319.84 & 10352.07 \\
\hline Bachoco (Francisco Robinson Bours-Castelo) & 14437.4 & 18208.8 & 15286.38 & 17068.65 & 2779.34 & 3555.97 \\
\hline Grupo Acerero del Norte (Xavier Autrey Maza and Alonso Ancira Elizondo) & 22718.0 & 27379.0 & 40265.28 & 36682.58 & 28760.92 & 24455.05 \\
\hline Casas Geo (Luis Orvañanos Lascurain) & 10091.3 & 14975.6 & 13495.70 & 14883.51 & 8434.81 & 8268.62 \\
\hline Arca (Manuel Barragán Morales and Miguel Fernández Iturriza) & 14647.0 & 18572.7 & 14178.57 & 15602.39 & 3832.05 & 4216.86 \\
\hline Kimberly-Clark (Claudio X. González Laporte and Pablo González Guajardo) & 21983.1 & 21480.2 & 25247.33 & 22765.19 & 13288.07 & 13391.29 \\
\hline Fragua (Javier Arroyo Chávez) & 9832.2 & 14575.2 & 3811.36 & 4594.67 & 1732.44 & 1997.68 \\
\hline Grupo Posadas (Gastón Azcárraga Andrade) & 5126.8 & 25948.9 & 11865.63 & 17941.06 & 6592.01 & 13800.81 \\
\hline Grupo Simec (Rufino Vigil González) & 16219.0 & 27640.1 & 19314.24 & 19489.57 & 6230.40 & 4753.55 \\
\hline Urbi (Cuauhtémoc Peréz Román Urbi) & 8194.3 & 12779.4 & 12376.05 & 16218.86 & 5625.48 & 7723.27 \\
\hline Grupo Kuo (Fernando Senderos Mestre) & 24577.4 & 22722.8 & 24460.23 & 20343.34 & 11647.73 & 11301.86 \\
\hline Corporación Durango (Miguel Rincón Arredondo) & 8150.4 & 15430.0 & 14400.00 & 14653.13 & 9600.00 & 9768.75 \\
\hline Quálitas Compañía de Seguros (Joaquín Brockman Lozano) & 4450.3 & 8593.4 & 4955.84 & 11031.07 & 4129.87 & 10028.25 \\
\hline Alsea (Cosme Alberto Torrado Martínez) & 4318.3 & 7047.3 & 3039.07 & 4369.28 & 1266.28 & 1820.53 \\
\hline Grupo Lamosa (Federico Toussaint Elosúa) & 3782.0 & 6817.3 & 5494.06 & 11423.86 & 2616.22 & 8159.90 \\
\hline Grupo Continental (Cynthia Helena Grossman) & 10623.8 & 12283.3 & 8900.13 & 9394.08 & 1934.81 & 1957.10 \\
\hline Interacciones (Carlos Hank Rhon) & 1773.3 & 11055.1 & 9412.80 & 3098.05 & 7844.00 & 1032.68 \\
\hline Grupo Embotelladoras Unidas (Juan Gallardo Thurlow) & 6304.3 & 7713.6 & 4664.87 & 3841.39 & 2028.21 & 1670.17 \\
\hline Consorcio ARA (Gemán Ahumada Russek) & 6772.7 & 9257.3 & 9685.22 & 11543.01 & 2934.92 & 4439.62 \\
\hline Minera Autlán (José Antonio Rivero Larrea) & 2097.9 & 2461.7 & 2667.11 & 2917.99 & 919.69 & 1080.74 \\
\hline Grupo Cementos de Chihuahua (Federico Terrazas Torres) & 4722.9 & 8453.2 & 11159.42 & 15641.39 & 3985.51 & 7109.72 \\
\hline Grupo Aeroportuario del Sureste (Fernando Chico Pardo) & 2063.8 & 2785.9 & 14114.58 & 15967.29 & 1037.84 & 2073.67 \\
\hline Ixe Grupo Financiero (Enrique Luis Castillo Sánchez Mejorada) & 2261.7 & 6460.0 & 22641.67 & 15410.96 & 20583.33 & 12842.47 \\
\hline Grupo Gigante (Ángel Losada Moreno) & 32524.6 & 27115.3 & 28514.10 & 27583.94 & 12397.44 & 11493.31 \\
\hline Promotora Ambiental (Alberto Garza Santos) & 2096.5 & 3004.5 & 2477.71 & 2843.04 & 952.96 & 1292.29 \\
\hline Verzatec (Eugenio Clariond Reyes) & 39182.1 & 7148.4 & 35469.47 & 33221.82 & 15421.51 & 10381.82 \\
\hline Promotora y Operación de Infraestructura (David Peñalosa Sandoval) & 2645.8 & 2715.5 & 6450.18 & 10620.09 & 5863.80 & 9654.63 \\
\hline Corporación Interamericana de Entretenimiento (Alejandro Soberón Kuri) & 8658.9 & 10187.9 & 15672.84 & 9786.37 & 9795.52 & 6116.48 \\
\hline SANLUIS Rassini (Antonio Madero Bracho) & 6841.0 & 7999.7 & 8190.48 & 3200.63 & 5119.05 & 2133.75 \\
\hline Grupo Transportación Marítima Mexicana (José Francisco Serrano Segovia) & 3260.5 & 3306.8 & 8631.50 & 12156.15 & 7192.91 & 10130.12 \\
\hline Grupo Martí (Alfredo Harp Helú) & 2322.7 & 3282.0 & 2969.70 & 3442.50 & 1414.14 & 1912.50 \\
\hline Internacional de Cerámica (Óscar Almeida Chabre) & 4462.0 & 5503.4 & 4465.51 & 4629.50 & 2480.84 & 2571.94 \\
\hline Corporacion Mexicana de Restaurantes (Joaquín Vargas Guajardo) & 1137.4 & 1643.7 & 1092.86 & 1366.47 & 242.86 & 440.80 \\
\hline Mifiel Grupo Financiero (Daniel Becker Feldman) & 1248.7 & 2597.1 & 4877.78 & 14532.45 & 4064.81 & 13211.31 \\
\hline
\end{tabular}


(continued)

\begin{tabular}{|c|c|c|c|c|c|c|}
\hline \multirow{2}{*}{ Business groups/enterprises } & \multicolumn{2}{|c|}{ Sales } & \multicolumn{2}{|c|}{ Total assets } & \multicolumn{2}{|c|}{ Total liabilities } \\
\hline & 2005 & 2007 & 2005 & 2007 & 2005 & 2007 \\
\hline Invex Grupo Financiero (Juan Guichard Michel) & 889.7 & 3976.9 & 9137.36 & 11682.19 & 7028.74 & $8,986.30$ \\
\hline Grupo Mexicano de Desarrollo (Jorge Ballesteros Franco) & 1080.1 & 1517.9 & 3866.10 & 3734.13 & 1431.89 & 1383.01 \\
\hline Grupo Collado (Guillermo Vogel Hinojosa) & 4954.2 & 5883.2 & 3371.43 & 4330.19 & 2107.14 & 3092.99 \\
\hline Médica Sur (Misael Uribe Esquivel y Manuel Martínez López) & 1069.4 & 1397.2 & 1566.65 & 1742.52 & 540.23 & 528.04 \\
\hline Monex Grupo Financiero (Héctor Lagos Cué and Héctor Lagos Dondé) & 1335.0 & 2232.0 & 2399.51 & 1975.28 & 1090.69 & 1097.38 \\
\hline Grupo Industrial Saltillo (Ernesto López de Nigris and Juan Carlos López Villarreal) & 9518.2 & 8823.7 & 12366.67 & 10480.18 & 6183.33 & 4556.60 \\
\hline Grupo Famsa (Humberto Garza González) & 10611.3 & 14181.2 & 10968.49 & 14029.05 & 7312.33 & 8252.38 \\
\hline Grupo Casa Saba (Isaac Saba Raffoul) & 21829.3 & 25126.5 & 10008.28 & 11157.17 & 5267.52 & 5872.20 \\
\hline Grupo Bafar (Óscar Eugenio Baeza Farés) & 3407.6 & 4318.7 & 2741.74 & 3330.13 & 1096.70 & 1189.33 \\
\hline Sare (Dionisio Sánchez Carbajal) & 3370.7 & 4899.2 & 4926.07 & 5364.84 & 1894.64 & 2554.69 \\
\hline Grupo la Moderna (Eduardo Monroy Cárdenas) & 3676.1 & 4651.8 & 4216.38 & 4035.01 & 795.54 & 733.64 \\
\hline Grupo Ruba (Enrique Terrazas Torres) & 2557.0 & 4567.6 & 2511.22 & 3587.37 & 1141.47 & 1559.72 \\
\hline Copamex (Juan Bosco Maldonado Quiroga) & 4724.7 & 5562.5 & 6800.00 & 7287.80 & 3400.00 & 3643.90 \\
\hline Grupo Minsa (Raymundo, Armando, Alfonso and Guillermo Gómez Flores) & 2214.2 & 3033.1 & 2085.12 & 2604.64 & 347.52 & 685.43 \\
\hline Grupo Accel (Eloy Vallina Lagüera) & 1537.3 & 1726.1 & 1713.13 & 1628.85 & 535.35 & 542.95 \\
\hline
\end{tabular}

Source: Prepared by the authors on the basis of data obtained from the journal Expansion and from the National Institute of Statistics, Geography and Information (INEGI).

ANNEX 2

Basic statistics for the econometric regressions, 2005-2007

(Millions of pesos at current prices)

\begin{tabular}{|c|c|c|c|c|c|c|}
\hline \multirow{2}{*}{ Business groups/enterprises } & \multicolumn{2}{|c|}{ Equity } & \multicolumn{2}{|c|}{ Net profit } & \multicolumn{2}{|c|}{ Ratio sales/assets } \\
\hline & 2005 & 2007 & 2005 & 2007 & 2005 & 2007 \\
\hline Grupo Carso, América Móvil, Imbursa (Carlos Slim Helú \& Sons) & 297437.55 & 293383.12 & 70492.7 & 122370.1 & 0.74 & 0.79 \\
\hline Cemex (Lorenzo Zambrano Treviño) & 109926.96 & 138797.45 & 22425.1 & 26107.8 & 0.56 & 0.64 \\
\hline Grupo México (Germán Larrea Mota Velasco) & 58048.78 & 52627.58 & 7140.0 & 18356.5 & 0.58 & 0.99 \\
\hline Fomento Económico Mexicano (José Antonio Fernández Carbajal) & 66860.24 & 54275.51 & 5549.4 & 8510.4 & 0.83 & 1.48 \\
\hline Grupo Alfa (Dionisio Garza Medina) & 32458.75 & 33032.56 & 7790.1 & 3551.0 & 1.12 & 1.44 \\
\hline Grupo Modelo (Carlos Fernánez González) & 68142.99 & 58588.78 & 7291.3 & 9503.1 & 0.62 & 1.02 \\
\hline Gruma y Banorte (Roberto González Barrera) & 40078.07 & 37392.56 & 7494.6 & 9744.5 & 0.27 & 0.43 \\
\hline Grupo Bimbo (Daniel Servitje Montull) & 19783.92 & 23169.00 & 2829.1 & 3811.3 & 1.55 & 1.96 \\
\hline Grupo Bal (Alberto Bailléres González) & 21785.31 & 29887.97 & 3115.3 & 5762.4 & 0.75 & 0.81 \\
\hline Grupo Salinas Elektra (Ricardo Salinas Pliego) & 11683.51 & 20486.23 & 5386.1 & 6324.1 & 0.67 & 0.69 \\
\hline Organización Soriana (Ricargo Martín Bringas) & 20882.35 & 24002.30 & 2130.0 & 3134.7 & 1.35 & 1.21 \\
\hline Grupo Televisa (Emilio Azcárraga Jean) & 42835.66 & 35049.87 & 6125.5 & 8082.5 & 0.41 & 0.49 \\
\hline Mexichem (Antonio del Valle Ruiz) & 34136.61 & 4601.27 & 6247.0 & 2108.3 & 0.10 & 1.50 \\
\hline Grupo Coppel (Enrique Coppel Luken) & 8326.02 & 11311.28 & 1024.1 & 2616.3 & 1.05 & 1.02 \\
\hline Empresas ICA (Bernardo Quintana Isaac) & 12864.10 & 9623.92 & 501.7 & -893.1 & 0.59 & 1.22 \\
\hline Comercial Mexicana (Guillermo González Nova and Carlos González Zabalegui) & 16610.91 & 19029.04 & 1827.2 & 2555.6 & 1.32 & 1.44 \\
\hline Liverpool (Max David Michel and Max Michel Souberville) & 19334.04 & 22968.82 & 2726.1 & 3831.2 & 0.87 & 1.02 \\
\hline Axtel y Avantel (Tomás Milmo Santos) & 7123.26 & 7462.01 & 306.3 & 491.0 & 0.46 & 0.73 \\
\hline Grupo Xignux (Eugenio Garza Herrera) & 6321.43 & 5661.27 & 531.0 & 1049.6 & 1.43 & 3.07 \\
\hline Homex (Eustaquio Tomás de Nicolás Gutiérrez) & 5823.89 & 7246.45 & 1048.3 & 2193.5 & 0.61 & 0.92 \\
\hline Bachoco (Francisco Robinson Bours-Castelo) & 12507.04 & 13512.68 & 1776.0 & 1278.3 & 0.94 & 1.07 \\
\hline Grupo Acerero del Norte (Xavier Autrey Maza and Alonso Ancira Elizondo) & 11504.37 & 12227.53 & 2634.5 & 1972.3 & 0.56 & 0.75 \\
\hline Casas Geo (Luis Orvañanos Lascurain) & 5060.89 & 6614.89 & 1138.7 & 1448.0 & 0.75 & 1.01 \\
\hline Arca (Manuel Barragán Morales and Miguel Fernández Iturriza) & 10346.52 & 11385.53 & 1934.8 & 2501.4 & 1.03 & 1.19 \\
\hline Kimberly-Clark (Claudio X. González Laporte and Pablo González Guajardo) & 11959.26 & 9373.90 & 2906.1 & 3728.0 & 0.87 & 0.94 \\
\hline Fragua (Javier Arroyo Chávez) & 2078.92 & 2596.99 & 463.6 & 672.1 & 2.58 & 3.17 \\
\hline Grupo Posadas (Gastón Azcárraga Andrade) & 5273.61 & 4140.24 & 379.7 & 135.8 & 0.43 & 1.45 \\
\hline
\end{tabular}

(continues overleaf) 
(continued)

\begin{tabular}{|c|c|c|c|c|c|c|}
\hline \multirow{2}{*}{ Business groups/enterprises } & \multicolumn{2}{|c|}{ Equity } & \multicolumn{2}{|c|}{ Net profit } & \multicolumn{2}{|c|}{ Ratio sales/assets } \\
\hline & 2005 & 2007 & 2005 & 2007 & 2005 & 2007 \\
\hline Grupo Simec (Rufino Vigil González) & 13083.84 & 14736.02 & 1295.3 & 1791.9 & 0.84 & 1.42 \\
\hline Urbi (Cuauhtémoc Peréz Román Urbi) & 6750.57 & 8495.60 & 1174.6 & 1832.5 & 0.66 & 0.79 \\
\hline Grupo Kuo (Fernando Senderos Mestre) & 12812.50 & 9041.48 & 307.5 & -828.2 & 1.00 & 1.12 \\
\hline Corporación Durango (Miguel Rincón Arredondo) & 4800.00 & 4884.38 & 52.8 & -312.6 & 0.57 & 1.05 \\
\hline Quálitas Compañía de Seguros (Joaquín Brockman Lozano) & 825.97 & 1002.82 & -63.6 & 35.5 & 0.90 & 0.78 \\
\hline Alsea (Cosme Alberto Torrado Martínez) & 1772.79 & 2548.75 & 260.6 & 478.4 & 1.42 & 1.61 \\
\hline Grupo Lamosa (Federico Toussaint Elosúa) & 2877.84 & 3263.96 & 506.5 & 900.2 & 0.69 & 0.60 \\
\hline Grupo Continental (Cynthia Helena Grossman) & 6965.32 & 7436.98 & 1205.0 & 1604.9 & 1.19 & 1.31 \\
\hline Interacciones (Carlos Hank Rhon) & 1568.80 & 2065.37 & 196.1 & 603.5 & 0.19 & 3.57 \\
\hline Grupo Embotelladoras Unidas (Juan Gallardo Thurlow) & 2636.67 & 2171.22 & 158.2 & 294.2 & 1.35 & 2.01 \\
\hline Consorcio ARA (Gemán Ahumada Russek) & 6750.31 & 7103.39 & 1100.3 & 1339.7 & 0.70 & 0.80 \\
\hline Minera Autlán (José Antonio Rivero Larrea) & 1747.41 & 1837.25 & 202.7 & 296.9 & 0.79 & 0.84 \\
\hline Grupo Cementos de Chihuahua (Federico Terrazas Torres) & 7173.91 & 8531.66 & 990.0 & 1670.5 & 0.42 & 0.54 \\
\hline Grupo Aeroportuario del Sureste (Fernando Chico Pardo) & 13076.74 & 13893.62 & 562.3 & 522.4 & 0.15 & 0.17 \\
\hline Ixe Grupo Financiero (Enrique Luis Castillo Sánchez Mejorada) & 2058.33 & 2568.49 & 123.5 & -75.0 & 0.10 & 0.42 \\
\hline Grupo Gigante (Ángel Losada Moreno) & 16116.67 & 16090.63 & -96.7 & 4722.6 & 1.14 & 0.98 \\
\hline Promotora Ambiental (Alberto Garza Santos) & 1524.74 & 1550.75 & 147.9 & 93.2 & 0.85 & 1.06 \\
\hline Verzatec (Eugenio Clariond Reyes) & 20047.96 & 22840.00 & 1964.7 & 285.5 & 1.10 & 0.22 \\
\hline Promotora y Operación de Infraestructura (David Peñalosa Sandoval) & 586.38 & 965.46 & 163.6 & 547.9 & 0.41 & 0.26 \\
\hline Corporación Interamericana de Entretenimiento (Alejandro Soberón Kuri) & 5877.31 & 3669.89 & -1269.5 & -569.2 & 0.55 & 1.04 \\
\hline SANLUIS Rassini (Antonio Madero Bracho) & 3071.43 & 1066.88 & -21.5 & -982.7 & 0.84 & 2.50 \\
\hline Grupo Transportación Marítima Mexicana (José Francisco Serrano Segovia) & 1438.58 & 2026.02 & 1827.0 & -731.8 & 0.38 & 0.27 \\
\hline Grupo Martí (Alfredo Harp Helú) & 1555.56 & 1530.00 & 112.0 & 76.5 & 0.78 & 0.95 \\
\hline Internacional de Cerámica (Óscar Almeida Chabre) & 1984.67 & 2057.55 & 271.9 & 28.6 & 1.00 & 1.19 \\
\hline Corporacion Mexicana de Restaurantes (Joaquín Vargas Guajardo) & 850.00 & 925.68 & 47.6 & 82.2 & 1.04 & 1.20 \\
\hline Mifiel Grupo Financiero (Daniel Becker Feldman) & 812.96 & 1321.13 & 87.8 & 79.4 & 0.26 & 0.18 \\
\hline Cydsa (Tomás González Sada) & 4402.67 & 4205.02 & -330.2 & 100.5 & 0.66 & 0.91 \\
\hline Invex Grupo Financiero (Juan Guichard Michel) & 2108.62 & 2695.89 & 122.3 & 196.8 & 0.10 & 0.34 \\
\hline Grupo Mexicano de Desarrollo (Jorge Ballesteros Franco) & 2434.21 & 2351.12 & 185.0 & 136.6 & 0.28 & 0.41 \\
\hline Grupo Collado (Guillermo Vogel Hinojosa) & 1264.29 & 1237.20 & 53.1 & -45.9 & 1.47 & 1.36 \\
\hline Médica Sur (Misael Uribe Esquivel and Manuel Martínez López) & 1026.43 & 1214.49 & 143.7 & 216.3 & 0.68 & 0.80 \\
\hline Monex Grupo Financiero (Héctor Lagos Cué y Héctor Lagos Dondé) & 1308.82 & 877.90 & 267.0 & 370.3 & 0.56 & 1.13 \\
\hline Grupo Industrial Saltillo (Ernesto López de Nigris and Juan Carlos López Villarreal) & 6183.33 & 5923.58 & 74.2 & 364.3 & 0.77 & 0.84 \\
\hline Grupo Famsa (Humberto Garza González) & 3656.16 & 5776.67 & 266.9 & 519.9 & 0.97 & 1.01 \\
\hline Grupo Casa Saba (Isaac Saba Raffoul) & 4740.76 & 5284.98 & 744.3 & 921.7 & 2.18 & 2.25 \\
\hline Grupo Bafar (Óscar Eugenio Baeza Farés) & 1645.05 & 2140.80 & 365.2 & 193.1 & 1.24 & 1.30 \\
\hline Sare (Dionisio Sánchez Carbajal) & 3031.43 & 2810.16 & 318.3 & 487.0 & 0.68 & 0.91 \\
\hline Grupo la Moderna (Eduardo Monroy Cárdenas) & 3420.83 & 3301.37 & 328.4 & 361.5 & 0.87 & 1.15 \\
\hline Grupo Ruba (Enrique Terrazas Torres) & 1369.76 & 2027.64 & 339.7 & 579.5 & 1.02 & 1.27 \\
\hline Copamex (Juan Bosco Maldonado Quiroga) & 3400.00 & 3643.90 & 17.0 & 74.7 & 0.69 & 0.76 \\
\hline Grupo Minsa (Raymundo, Armando, Alfonso and Guillermo Gómez Flores) & 1737.60 & 1919.21 & 420.5 & 125.9 & 1.06 & 1.16 \\
\hline Grupo Accel (Eloy Vallina Lagüera) & 1177.78 & 1085.90 & 21.2 & 49.3 & 0.90 & 1.06 \\
\hline
\end{tabular}

Source: Prepared by the authors on the basis of data obtained from the journal Expansión and from the National Institute of Statistics, Geography and Information (INEGI). 


\section{Bibliography}

Basave, J. and M. Hernández (coords.) (2007), Los estudios de empresarios y empresa: una perspectiva internacional, Mexico City, Institute of Economic Research, National Autonomous University of Mexico.

Batchikov, S. and I. Petrov (1997), "The formation of financialindustrial groups and the estate", Russian and East European Finance and Trade, vol. 33, No. 1, Armonk, M.E. Sharpe, Inc., January-February.

Calderón, Á. (2006), "The expansion model of the major Chilean retail chains", CEPAL Review, No. 90 (LC/G.2323-P), Santiago, Chile, Economic Commission for Latin America and the Caribbean (ECLAC), December.

Castañeda, G. (2004), "Los grupos económicos como estabilizadores financieros de la economía mexicana 1996-2000", Problemas del desarrollo, vol. 35, No. 136, Mexico City, Institute of Economic Research, National Autonomous University of Mexico, January-March.

Cerutti, M., I. Ortega and Lylia Palacios (2000), "Empresarios y empresas en el norte de México: Monterrey, del Estado oligárquico a la globalización", European Review of Latin American and Caribbean Studies, No. 69, Amsterdam, Center for Latin American Research and Documentation, October.

Chavarín, R. (2006), "La arquitectura organizacional y gobierno corporativo de los grupos económicos en México", Ciencia Ergo Sum, vol. 13, No. 2, Toluca, Universidad Autónoma del Estado de México (UAMEX), July-October.

Correa. E. (2000), "Conglomerados y reforma financiera", Comercio exterior, vol. 49, No. 6, Mexico City, Bancomext, June.

Expansión, S.A. de C.V. (2008), "Los 100 empresarios más importantes de México", Expansión, Mexico City, Grupo Editorial Expansión, 28 April-11 May.

(2007), "Los 100 empresarios más importantes de México”, Expansión, Mexico City, Grupo Editorial Expansión, 30 April -15 May.

(2006), "Los 100 empresarios más importantes de México", Expansión, Mexico City, Grupo Editorial Expansión, 31 May -14 June.

(2005), "Los 100 empresarios más importantes de México”, Expansión, Mexico City, Grupo Editorial Expansión, 4-18 May.

Fernández, A. (2000), "América Latina: el debate sobre los nuevos grupos económicos y conglomerados industriales después de la reestructuración neoliberal", European Review of Latin American and Caribbean Studies, No. 69, Amsterdam, Center for Latin American Research and Documentation, October.

Garrido, C. (2002), "Industrialización y grandes empresas en el desarrollo estabilizador, 1958-1970", Análisis económico, vol. 17, No. 35, Azcapotzalco, D.F., Autonomous Metropolitan University.

(2001), "Estrategias empresariales ante el cambio estructural en México", Comercio exterior, vol. 67, No. 12, Mexico City, Bancomext, December.

(1997), "Las grandes empresas privadas nacionales mexicanas", Nueva sociedad, No. 151, Caracas, Friedrich Ebert Foundation, September-October.
Garrido, C. and C. Ortiz (2008), "Instituciones, actores y mercados en el cambio empresarial. El caso de Cemex y Vitro", Mexico City, UAM-Xochimilco.

Guillén, M. (2000), "Business groups in emerging economies: a resource-based view", Academy of Management Journal, vol. 43, No. 3, June, Briarcliff Manor, Academy of Management.

Hober, G. and G. Phillips (2008), "Real and financial industry booms and busts", NBER Working Papers Series, No. 14290, Cambridge, Massachusetts, National Bureau of Economic Research, August [online] http://www.nber.org/papers/ w14290.

Huerta, P. and J.E. Navas (2007), "Análisis de la relación entre la diversificación y los resultados empresariales: una visión teórica", Análisis económico, vol. 22, No. 49, Azcapotzalco, D.F., Autonomous Metropolitan University, January-April.

IMF (International Monetary Fund) (2009), International Financial Statistics, Washington, D.C.

Khanna, T. and Y. Yafeh (2007), "Business groups in emerging markets: paragons or parasites?", Journal of Economic Literature, vol. 45, Pittsburgh, American Economic Association Publications, July.

Levanti, C. (2001), "Prácticas empresariales y apertura económica en México", Comercio exterior, vol. 67, No. 12, Mexico City, Bancomext, December.

Mahmood, I. and W. Mitchell (2004), "Two faces: effects of business groups on innovation in emerging economies", Management Science, vol. 50, No. 10, Hanover, Informs, October.

Morck, R. and M. Nakamura (2007), "Business groups and the big push: Meiji Japan's mass privatization and subsequent growth”, NBER Working Papers Series, No. 13171, Cambridge, Massachusetts, National Bureau of Economic Research, June [online] http://www.nber.org/papers/w13171.

Mortimore, M. and W. Peres (2001), "Corporate competitiveness in Latin America and the Caribbean”, CEPAL Review, No. 74 (LC/G.2135-P), Santiago, Chile, Economic Commission for Latin America and the Caribbean (ECLAC), August.

Pérez, J.A. and F. Vela (2008), "Cambio en la concentración industrial manufacturera en el contexto de apertura comercial de México, 1980-2003”, Análisis económico, vol. 23, No. 52, Azcapotzalco, D.F., Autonomous Metropolitan University, January-April.

Rendón, A. (1997), "Grupos económicos en la década de los ochenta. Estrategia de diversificación o especialización", Economía: teoría y práctica, No. 8, Mexico City, UAM Xochimilco, January-June.

Rendón, A. and A. Morales (2008a), "Grupos económicos en la industria de alimentos: la estrategia de Gruma", Argumentos, No. 57, Mexico City, Autonomous Metropolitan University, May-August.

(2008b), "Estrategias de competencia (1987-2005)", Ide@s CONCYTEG, year 3, No. 41, Guanajuato, Mexico, Consejo de Ciencia y Tecnología del Estado de Guanajuato (CONCYTEG), November.

Salas-Porras, A. (2006a), "Los grupos mexicanos y coreanos ante el desmantelamiento del Estado", document presented at 
the 52 International Congress of Americanists (Sevilla, Spain, 17-21 July 2006).

(2006b), "Fuerzas centrípetas y centrífugas en red corporativa mexicana (1981-2001)", Revista mexicana de sociología, vol. 68, No. 2, Mexico City, National Autonomous University of Mexico, April-June.

Santiso, J. (2008), "The emergence of Latin multinationals", CEPAL Review, No. 95 (LC/G.2382-P), Santiago, Chile, Economic Commission for Latin America and the Caribbean (ECLAC), August.
Tarziján, J. and R. Paredes (2006), Organización industrial para la estrategia empresarial, Mexico City, Pearson Education.

Vázquez, M.A. (2004), "Grupos económicos en el norte de México", Problemas del desarrollo, vol. 35, No. 137, Mexico City, National Autonomous University of Mexico, April-June.

(1997), "Reestructuración económica y grupos empresariales en el norte de México", Economía y sociedad, No. 3, Ciudad Juárez, Universidad Autónoma de Ciudad Juárez, August. 